\title{
HUBUNGAN PENGGUNAAN KORTIKOSTEROID DENGAN KEJADIAN INFEKSI PADA PASIEN SINDROM NEFROTIK DI RUMAH SAKIT "X” JAKARTA
}

\author{
THE ASSOCIATION OF CORTICOSTEROID USE AND INFECTION IN \\ NEPHROTIC SINDROME PATIENTS IN HOSPITAL 'X' JAKARTA
}

\author{
Nurhasnah Nurhasnah*, Ridha Elvina, Diana Lestari \\ Fakultas Farmasi dan Sains Universitas Muhammadiyah Prof. Dr. Hamka \\ Islamic Center, Jl. Delima II/IV, Klender Jakarta Timur 13460 \\ *Penulis Korespodensi, email: nurhasnah@uhamka.ac.id
}

\begin{abstract}
ABSTRAK
Kortikosteroid merupakan terapi awal yang direkomendasikan pada pasien sindrom nefrotik (SN). Penggunaan kortikosteroid jangka panjang dapat meningkatkan risiko infeksi. Selain itu, SN sendiri juga dapat menyebabkan infeksi. Penelitian ini bertujuan untuk mendapatkan gambaran demografi, penggunaan kortikosteroid, kejadian infeksi pada pasien SN dan untuk melihat hubungan penggunaan kortikosteroid dengan kejadian infeksi. Metoda penelitian yang digunakan adalah case-control study dengan pendekatan retrospektif. Sebanyak 81 pasien SN selama periode 2014-2016 di Rumah Sakit X Jakarta memenuhi kriteria inklusi. Hasil penelitian ini menemukan pasien SN terdiri dari 41 pria dan 40 wanita dengan usia 33,01 $\pm 21,71$ tahun. Gambaran penggunaan kortikosteroid menunjukkan mayoritas pasien SN mendapatkan terapi kortikosteroid yaitu $61(75,31 \%)$ yang terdiri dari metilprednisolon $(40,74 \%)$, prednison $(33,34 \%)$ dan deksametason $(1,23 \%)$ dan sebanyak 20 (24,69\%) pasien tanpa kortikosteroid. Infeksi terjadi pada 39 pasien $(48,15 \%)$ dengan jumlah kasus infeksi tertinggi adalah infeksi saluran pernapasan akut (21 kasus) diikuti oleh infeksi saluran kemih (7 kasus). Hasil uji chi-square menunjukkan tidak ada hubungan yang signifikan antara infeksi dan kortikosteroid $(\mathrm{p}=0,401)$ dengan odds ratio [OR] 1,55 95\% CI 0,564,32. Dapat disimpulkan pasien SN yang menerima terapi kortikosteroid cenderung lebih mudah untuk mengalami infeksi daripada pasien SN yang tidak menggunakan terapi kortikosteroid.
\end{abstract}

Kata kunci: Sindrom nefrotik, kortikosteroid, infeksi

\section{ABSTRACT}

Corticosteroids are the initial therapy recommended in patients with Nephrotic Syndrome (NS). Long term corticosteroids use can increase infection risk. Moreover, $N S$ itself could also cause infection. The study aims were to obtain and overview of demography, corticosteroid use, infection incidence and to investigate the association between corticosteroid use and infection in NS patients. The research method used was case-control study with a retrospective approach. A total of 81 NS patients during the period 2014-2016 at X Jakarta Hospital met inclusion criteria. The results of this study 
found SN patients consist of 41 men and 40 women with age $33.01 \pm 21.71$ years. Overview corticosteroid use showed majority NS patient used corticosteroid (75.31\%) consisting of methylprednisolone (40.74\%), prednisone (33.34\%) and dexamethasone (1.23\%) respectively and as many as 20 (24.69\%) without corticosteroids. Infection occurred in 39 patients (48.15\%) with the highest number infection case was acute respiratory tract infection (21 cases) followed by urinary tract infection (7 cases). The chi-square showed no significant association between infection and corticosteroid ( $p=$ $0.401)$ with an odds ratio [OR] $1.5595 \%$ CI 0.56-4.32. It can be concluded that NS patients who receive corticosteroid therapy tend to be easier to get an infection than those without corticosteroid therapy.

Keywords: Nephrotic syndrome, corticosteroid, infection

\section{PENDAHULUAN}

Sindrom nefrotik (SN) adalah kelainan yang ditandai dengan peningkatan kadar protein dalam urin (proteinurea), hipoalbuminemia, edema dan hiperkolesterol (Hull and Goldsmith, 2008; Zolotas et al., 2016). SN dapat terjadi pada anak-anak dan juga orang dewasa. Angka kejadian SN pada anak-anak di Indonesia mencapai 6 kasus pertahun dari 100.000 anak berusia kurang dari 14 tahun dengan perbandingan anak laki-laki dan perempuan 2:1 (Alatas et al., 2005). Angka kejadian SN pada orang dewasa adalah tiga kasus baru per 100.000 setiap tahun (Hull and Goldsmith, 2008).

Terapi lini pertama pengobatan SN adalah kortikosteroid oral, dimana pada tahun 1960 kortikosteroid secara dramatis mampu mengurangi mortalitas (hingga 3\%) (Downie et al., 2017). Sekitar 92\% anak-anak dengan SN idiopatik akan memasuki remisi di awal terapi dan diklasifikasikan memiliki Sindrom Nefrotik Sensitif Steroid (SNSS), sementara 8\% gagal untuk remisi dan diklasifikasikan memiliki Sindrom Nefrotik Resisten Steroid (SNRS) (McCaffrey et al., 2016). Sebaliknya anak dengan SN yang tidak diterapi berhubungan dengan tingginya angka kematian yang sebagian besar adalah karena infeksi bakteri (KDIGO, 2012). KDIGO merekomendasikan terapi kortikosteroid (prednison) untuk episode awal SNSS pada anak-anak dengan dosis 2 $\mathrm{mg} / \mathrm{Kg} /$ hari maksimum $60 \mathrm{mg} /$ hari selama minimal $12 \mathrm{minggu}$ (KDIGO, 2012). Selain kortikosteroid, imunosupresan juga diindikasikan untuk SN terutama untuk SNRS seperti siklofosfamid, siklosforin dan rituximab (Downie et al., 2017).

Kortikosteroid bekerja dengan berbagai mekanisme dalam menghambat sistem imun sehingga penggunaannya dikaitkan dengan peningkatan kerentanan terhadap infeksi (Standbury and Graham, 1998) dan infeksi juga merupakan salah satu komplikasi yang paling serius pada pasien SN (Park and Shin, 2011). Pada pasien SN terjadi peningkatan kerentanan terhadap mikroorganisme karena pasien SN kehilangan IgG melalui ginjal dan zat-zat lain (faktor B dan faktor D) yang dibutuhkan untuk opsonisasi (Zolotas et al., 2016). Sepsis, peritonitis dan selulitis merupakan infeksi yang sering ditemukan pada pasein SN dengan beberapa mikroba penyebabnya antara lain Streptococcus pneumonia, $\beta$-hemolytic streptococci, Haemophilus dan bakteri gram negatif (Park and Shin, 2011).

Walaupun kejadian infeksi pada pasien SN telah berkurang di negara maju, tetapi di negara berkembang infeksi masih menjadi masalah utama (Park and Shin, 2011). 
Sebuah penelitian yang melibatkan 16,207 pasien rheumatoid arthritis menemukan terjadinya peningkatan kejadian infeksi setelah satu minggu menggunakan kortikosteroid yang setara dengan $5 \mathrm{mg}$ prednisone (Youssef et al., 2016). Tujuan dari penelitian ini adalah untuk melihat gambaran demografi, penggunaan kortikosteroid, kejadian infeksi dan hubungan kejadian infeksi dengan penggunaan kortikosteroid pada pasien SN di Rumah Sakit X Jakarta Periode 2014-2016.

\section{METODE PENELITIAN}

Penelitian dilakukan di bagian rekam medis salah satu rumah sakit swasta kelas B di daerah Jakarta Pusat dari bulan Juli-September 2017. Penelitian ini merupakan penelitian case-control study dengan pendekatan retrospektif. Kelompok case adalah pasien dengan diagnosa SN yang mendapatkan terapi kortikosteroid dan kelompok control adalah pasien dengan diagnosa SN yang tidak mendapatkan terapi kortikosteroid. Sampel pada penelitian ini adalah seluruh pasien dengan diagnosa SN yang berobat di rumah sakit X periode Januari 2014 sampai Desember 2016 yang memenuhi kriteria inklusi dan ekslusi.

Kriteria inklusi meliputi seluruh rekam medis pasien dengan diagnosa SN periode 2014-2016. Kriteria ekslusi adalah pasien SN yang pada saat didiagnosa SN sudah mengalami infeksi yang membutuhkan terapi jangka lama seperti tuberkulosis, HIV/AIDS atau hepatitis, dan pasien yang memiliki data rekam medis tidak lengkap (data laboratorium dan data pengobatan). Pasien dikatakan mengalami infeksi jika terdapat diagnosa infeksi pada rekam medis pasien setelah didiagnosa SN. Jenis infeksi yang diambil adalah semua jenis infeksi yang dialami pasien SN yang tercatat di rekam medis seperti hepatitis, tuberkulosis, infeksi saluran kemih, infeksi saluran pernafasan akut, bronkopneumonia, selulitis, diare dll. Diagnosa diare dikatakan merupakan kejadian infeksi jika ada hasil kultur dengan hasil diare positif disebabkan oleh mikroorganisme. Pada kelompok case, kejadian infeksi diambil jika pasien telah menggunakan kortikosteroid minimal selama 14 hari.

Berdasarkan respon pasien terhadap kortikosteroid, pasien SN dapat dibagi menjadi dua kelompok yaitu SN sensitif steroid (SNSS) dan SN resisten steroid (SNRS). Pasien SN dikatakan sensitif steroid jika terjadi remisi total (proteinuria $\leq 4 \mathrm{mg} / \mathrm{m}^{2}$ LPB/jam) dalam 4 minggu dengan pemberian steroid dosis penuh $(2 \mathrm{mg} / \mathrm{kg} \mathrm{BB} / \mathrm{hari})$. Pasien SN dikatan resisten steroid apabila setelah 4 minggu pengobatan steroid dosis penuh tidak terjadi remisi. Relaps jarang adalah relaps yang terjadi kurang dari 2 kali dalam enam bulan pertama setelah respon awal, atau kurang dari 4 kali per tahun. Relaps sering adalah relaps yang terjadi $\geq 2$ kali dalam 6 bulan pertama atau $\geq 4$ kali dalam periode satu tahun. Pasien SN dikatakan mengalami remisi jika tidak ditemukan protein di urin atau proteinurea $<4 \mathrm{mg} / \mathrm{m} 2 \mathrm{LPB} /$ jam selama 3 hari berturut-turut dalam waktu satu minggu (Alatas et al., 2005).

Data yang dikumpulkan meliputi karakteristik pasien (umur dan jenis kelamin), diagnosa (tipe SN dan jenis infeksi), data laboratorium (leukosit dan hasil kultur) dan data pengobatan (jenis terapi kortikosteroid dan lama pengobatan). Uji Chi-squre digunakan untuk melihat hubungan kejadian infeksi dengan penggunaan kortikosteroid sedangkan untuk melihat prevalensi kejadian infeksi digunakan nilai odds ratio. 


\section{HASIL DAN PEMBAHASAN}

Penelitian dilakukan dengan mengumpulkan data pasien dengan diagnosa SN selama tiga tahun (2014-2016) di RS " $\mathrm{X}$ " Jakarta Pusat melalui rekam medis pasien. Total pasien yang memenuhi kriteria inklusi pada penelitian adalah 81 pasien dari 95 pasien dan 14 pasien masuk kriteria ekslusi karena 1 pasien mengalami infeksi TB pada saat didiagnosa SN dan sisanya memiliki data rekam medis yang tidak lengkap. Didapatkan sebanyak 61 pasien pada kelompok case dan 20 pasien pada kelompok control. Data karakterisitik pasien dapat dilihat di tabel I.

Pada penelitian ini perbandingan pasien laki-laki dan perempuan hampir sama dan kelompok umur yang paling banyak menderita SN adalah umur 17-65 tahun. Keterkaitan SN dengan hormonal masih belum jelas, karena belum diketahuinya pengaruh hormon estrogen dan progesterone terhadap progresivitas kerusakan glomerulus (Neugarten et al. 2007).

Umur pasien terendah adalah di bawah satu tahun dan tertinggi 76 tahun. Ratarata umur pasien adalah $33,01 \pm 21,71$ tahun. SN memiliki banyak penyebab termasuk penyakit ginjal primer, glomerulosklerosis fokal dan nefropati membranosa selain itu SN juga dapat terjadi sebagai akibat dari penyakit sistemik yang mempengaruhi organ lain (Cohen, 2016). SN pada anak-anak lebih sering bersifat idiopathic atau tidak diketahui penyebabnya (Jaipul, 2018) sedangkan pada dewasa sindrom nefrotik paling sering disebabkan oleh gangguan sistemik (Hadisaputro et al., 2011). Berdasarkan respon pasien terhadap korikosteroid, ditemukan pasien SN relaps jarang $(77,78 \%)$ lebih banyak dibandingkan dengan relaps sering $(22,22 \%)$ dan tidak ditemukan pasien yang resisten terhadap kortikosteroid pada penelitian ini.

Kortikosteroid yang paling banyak digunakan adalah methylprednisolon (40,74\%) dan diikuti prednison (33,34\%). Pada penelitian ini tidak semua pasien dengan diagnosa SN mendapatkan terapi kortikosteroid karena adanya keadaan klinis tertentu yang tidak dianjurkan untuk mendapatkan terapi tersebut. Dari 20 pasien yang tidak mendapatkan kortikosteroid, 8 diantaranya mengalami infeksi, 3 pasien mengalami sirosis hati dan 9 pasien dengan diabetes melitus. Selain kortikosteroid, obat lain yang diberikan kepada pasien pada penelitian ini adalah diuretik (furosemid), ACEI/ Angiotensin Converting Enzyme Inhibitor (captopril) dan antibiotik (untuk pasien yang mengalami infeksi). 
Tabel I. Karakterisitik pasien sindrom nefrotik di Rumah Sakit "X” Jakarta

\begin{tabular}{|c|c|c|}
\hline Kategori/Karakterisitik Pasien & Jumlah (n=81) & Persentase \% \\
\hline \multicolumn{3}{|l|}{ Jenis kelamin } \\
\hline a. Laki-laki & 41 & $50,62 \%$ \\
\hline b. Perempuan & 40 & $49,38 \%$ \\
\hline \multicolumn{3}{|l|}{ Usia (Tahun) } \\
\hline a. $0-16$ & 22 & $27,16 \%$ \\
\hline b. $17-65$ & 52 & $64,2 \%$ \\
\hline c. $>65$ & 7 & $8,64 \%$ \\
\hline Rerata Usia \pm Standar Deviasi & \multicolumn{2}{|c|}{$33,01 \pm 21,71$ tahun } \\
\hline \multicolumn{3}{|l|}{ Jenis Sindrom Nefrotik } \\
\hline a. Sindrom nefrotik relaps jarang & 63 & $77,78 \%$ \\
\hline b. Sindrom nefrotik relaps sering & 18 & $22,22 \%$ \\
\hline \multicolumn{3}{|l|}{ Penggunaan kortikosteroid } \\
\hline a. Prednison & 27 & $33,33 \%$ \\
\hline b. Methylprednisolon & 33 & $40,74 \%$ \\
\hline c. Dexametason & 1 & $1,23 \%$ \\
\hline d. Tanpa kortikosteroid & 20 & $24,69 \%$ \\
\hline \multicolumn{3}{|l|}{ Lama penggunaan kortikosteroid } \\
\hline a. $<2$ bulan & 23 & $37,7 \%$ \\
\hline b. $2-5$ bulan & 23 & $37,7 \%$ \\
\hline c. $>5$ bulan & 15 & $24,6 \%$ \\
\hline Rerata Lama Penggunaan Obat \pm Standar Deviasi & \multicolumn{2}{|c|}{$3,61 \pm 3,08$ bulan } \\
\hline \multicolumn{3}{|l|}{ Kejadian infeksi } \\
\hline a. Ada kejadian infeksi & 39 & $48,15 \%$ \\
\hline b. Tidak ada kejadian infeksi & 42 & $51,85 \%$ \\
\hline
\end{tabular}

Pasien SN membutuhkan terapi kortikosteroid jangka lama dapat mencapai 12 bulan. Pada penelitian ini rata-rata pasien meminum kortikosteroid 3,61 $\pm 3,08$ bulan yang tersingkat adalah 0,5 bulan dan yang terlama 14 bulan. Salah satu efek samping penggunaan korikosteroid adalah meningkatnya kejadian infeksi. Dalam suatu systematic review dikatakan bahwa infeksi merupakan kejadian paling serius yang tidak diinginkan dari penggunaan kortikosteroid dimana kasusnya terjadi pada 9\% pasien dan menyebabkan 21 kematian (Aljebab et al., 2017). Distribusi kejadian infeksi di rumah sakit "X" Jakarta pada pasien SN berdasarkan jenis kortikosteroid bisa dilihat di tabel II. 
Tabel II. Distribusi kejadian infeksi berdasarkan jenis kortikosteroid pada pasien sindrom nefrotik di Rumah Sakit "X" Jakarta

\begin{tabular}{|c|c|c|c|c|c|}
\hline \multirow{3}{*}{ Kategori } & \multicolumn{4}{|c|}{ INFEKSI } & \multirow{3}{*}{ Jumlah } \\
\hline & \multicolumn{2}{|c|}{$\mathbf{Y a}$} & \multicolumn{2}{|c|}{ Tidak } & \\
\hline & $\mathrm{N}$ & $\%$ & $\mathrm{~N}$ & $\%$ & \\
\hline \multicolumn{6}{|l|}{ Kortikosteroid } \\
\hline 1. Prednison & 17 & 62,96 & 10 & 37,04 & 27 \\
\hline 2. Methylprednisolon & 14 & 42,42 & 19 & 57,58 & 33 \\
\hline 3. Dexametason & 0 & 0 & 1 & 100 & 1 \\
\hline Jumlah & & & & & 61 \\
\hline Non Kortikosteroid & 8 & 40 & 12 & 60 & 20 \\
\hline Total Keseluruhan & 39 & 48,15 & 42 & 51,85 & $81(100 \%)$ \\
\hline
\end{tabular}

Hampir setengah pasien (48,15\%) dengan diagnosa SN mengalami infeksi. Persentase ini lebih tinggi dari penelitian yang dilakukan di India dimana kejadian infeksi terjadi 36,6\% pada pasien anak di bawah 13 tahun (Ajayan et al., 2013). Infeksi merupakan komplikasi SN yang serius. Kejadian Infeksi dapat disebabkan oleh penyakit SN yang menyebabkan meningkatnya kerentanan terhadap mikroorganisme karena hilangnya IgG dan zat penting lain (faktor B dan D) untuk opsonisasi (Moorani et al., 2011; Zolotas et al. 2016).

Berdasarkan jenis kortikosteroid, kejadian infeksi lebih sering terjadi pada pasien yang mendapatkan prednison yaitu 17 (62,96\%) kasus infeksi dari 27 pasien. Kejadian infeksi pada penggunaan methylprednisolon adalah $14(42,42 \%)$ kejadian infeksi dari 33 pasien. Kejadian infeksi hanya muncul sebanyak 8 (40\%) kasus dari 20 pasien SN yang tidak mendapatkan kortikosteroid. Pada penelitian ada variabel perancu yang tidak dapat dikontrol seperti pengaruh lingkungan, riwayat penyakit keluarga dan pasien, adanya Kejadian Luar Biasa (KLB) dan riwayat imunisasi pasien.

Prednison diberikan untuk mengatasi proteinuria yang diakibatkan karena glomerulus tidak bisa melakukan filtrasi dengan baik sehingga protein yang seharusnya tidak difiltrasi dapat lolos melalui urin (Sweetman, 2011). Pada penelitian ini pasien SN dengan terapi prednison mengalami kejadian infeksi paling tinggi dibandingkan kortikosteroid lainnya. Berbagai penelitian memberikan hasil yang konsisten tentang terjadi peningkatan kejadian infeksi pada pasien yang menggunakan prednison bahkan pada dosis $5 \mathrm{mg}$ atau bahkan kurang dari $5 \mathrm{mg}$ per hari (Youssef et al., 2016). Pada penelitin lain juga ditemukan terjadinya peningkatan infeksi bakteri yang serius (odds ratio 1,3) pada penggunaan prednison jangka lama (Youssef et al., 2016).

Methyilprednisolon merupakan kortikosteroid yang paling banyak digunakan pada penelitian ini. Methylprednisolon merupakan kortikosteroid dengan aktifitas utamanya adalah glukokortikoid (Sweetman, 2009). Methylprednisolon memiliki aktifitas antiinlamasi yang lebih tinggi dibandingkan prednison (5:4) (Katzung, 2018). 
Peningkatan kejadian infeksi seperti tuberkulosis, infeksi jamur dan infeksi virus telah dilaporkan terjadi pada pasien yang mendapatkan terapi methylprednisolon (Sweetman, 2011).

Pada penelitian ini muncul kejadian infeksi pada 39 pasien dari 81 total pasien (terlihat di tabel III). Masing-masing terdiri dari 31 pasien yang mendapatkan kortikosteroid dan 8 pasien yang tidak mendapatkan terapi kortiksteroid. Pada kedua kelompok terdapat kesamaan infeksi yang terjadi yaitu ISPA (Infeksi Saluran Nafas Akut), ISK (Infeksi Saluran Kemih), diare dan selulitis. Terdapat beberapa kejadian infeksi yang tidak muncul pada pasien yang tidak menggunakan kortikosteroid yaitu hepatitis, periodontitis, tuberkulosis dan selulitis.

Jenis infeksi yang paling banyak ditemukan pada pasien yang menerima kortikosteroid adalah ISPA yaitu 21(53,85\%) kasus. Kejadian infeksi ini lebih banyak muncul pada penggunaan prednison dibandingkan methylprednisolone dengan perbandingan 2:1. Tipe infeksi kedua yang banyak ditemukan adalah ISK yaitu sebanyak $7(17,95 \%)$ kasus. Kasus yang terbanyak terjadi pada pasien yang menggunakan methylprednisolon dengan kejadian 5 kali lebih banyak dibandingkan prednison.

Ditemukan dua kasus hepatitis yaitu hepatitis B dan hepatitis C. Hepatitis B terjadi pada pasien SN relaps jarang, jenis kelamin perempuan, usia 65 tahun dan mendapatkan methylprednisolon. Hepatitis muncul setelah 2 bulan menjalani terapi methylprednisolon. Hepatitis C muncul pada pasien SN relaps jarang, jenis kelamin perempuan, dan mendapatkan terapi prednisone. Hepatitis $\mathrm{C}$ muncul setelah pasien diterapi dengan prednisone selama 8 bulan. Kejadian hepatitis tidak muncul pada pasien yang tidak mendapatkan terapi kortikosteroid.

Penyakit tuberkulosis muncul pada satu pasien yang mendapatkan terapi prednison dengan jenis kelamin laki-laki, umur 55 tahun dengan SN relaps jarang. Penyakit tuberkulosis muncul setelah 16 hari menggunakan kortikosteroid. Infeksi perindotitis hanya muncul pada pasien yang mendapatkan terapi prednisone yaitu pasien perempuan dengan SN relaps sering, umur 41 tahun. Kejadian infeksi (perindotitis) muncul setelah 6 bulan mendapatkan terapi prednison

Tabel IV memberikan gambaran hubungan kejadian infeksi dengan lama penggunaan kortikosteroid. Hasil uji square menunjukkan ada hubungan yang signifikan $(\mathrm{p}=0,000)$ antara lama pemberian kortikosteroid dengan kejadian infeksi pada pasien sindrom nefrotik. Kejadian infeksi cenderung terjadi pada pasien yang menerima pengobatan kortikosteroid jangka panjang yaitu lebih dari 5 bulan. Dari 15 pasien yang mendapatkan terapi kortikosteroid, semuanya mengalami infeksi. Dari 23 pasien yang menggunakan obat dari 2-5 bulan 12 pasien mengalami infeksi. Pasien yang menggunakan kortikosteroid selama satu bulan, dari 23 pasien hanya 4 pasien yang mengalami infeksi. 
Tabel III. Jenis infeksi pada pasien sindrom nefrotik di Rumah Sakit "X” Jakarta

\begin{tabular}{lcccc}
\hline \multicolumn{1}{c}{ Jenis Infeksi } & \multicolumn{2}{c}{ Kortikosteroid } & $\begin{array}{c}\text { Non- } \\
\text { kortikosteroid }\end{array}$ & $\begin{array}{c}\text { Total Kejadian } \\
\text { Infeksi (\%) }\end{array}$ \\
\hline & $\mathbf{P ~ ( n )}$ & $\mathbf{M ~ ( n )}$ & $\mathbf{n}$ & \\
\hline Diare dan Gastroenteritis & - & 1 & 2 & $3(7,69 \%)$ \\
Hepatitis B & - & 1 & - & $1(2,56 \%)$ \\
Hepatitis C & 1 & - & - & $1(2,56 \%)$ \\
ISPA & 12 & 6 & 3 & $21(53,85 \%)$ \\
ISK & 1 & 5 & 1 & $7(17,95 \%)$ \\
Tuberkulosis & 1 & - & - & $1(2,56 \%)$ \\
Peridontitis & 1 & - & - & $1(2,56 \%)$ \\
Selulitis & 1 & - & - & $1(2,56 \%)$ \\
Infeksi bakteri lain & - & 1 & 1 & $2(5,13 \%)$ \\
Selulitis+bronchitis akut & - & - & 1 & $1(2,56 \%)$ \\
\hline & $\mathbf{1 7}$ & $\mathbf{1 4}$ & $\mathbf{8}$ & $\mathbf{3 9}$ \\
& $\mathbf{( 4 3 , 5 8 \% )}$ & $\mathbf{( 3 5 , 9 0 \% )}$ & $\mathbf{( 2 0 , 5 1 \% )}$ & $\mathbf{( 1 0 0 \% )}$ \\
\hline
\end{tabular}

Keterangan:

P: Prednison; M: Methylprednisolon; ISPA: Infeksi Saluran Pernapasan Akut; ISK: Infeksi Saluran Kemih.

Tabel IV. Hubungan lama terapi kortikosteroid dengan kejadian infeksi

\begin{tabular}{|c|c|c|c|c|}
\hline Kategori & \multicolumn{2}{|c|}{ Infeksi } & Jumlah & Uji Chi \\
\hline & Ya & Tidak & & Square \\
\hline$<2$ bulan & 4 & 19 & 23 & \\
\hline $2-5$ bulan & 12 & 11 & 23 & $\mathrm{P}=0,000$ \\
\hline$>5$ bulan & 15 & 0 & 15 & \\
\hline
\end{tabular}

Tabel V. Hubungan terapi kortikosteroid dengan kejadian infeksi

\begin{tabular}{lcccc}
\hline \multicolumn{1}{c}{ Kategori } & \multicolumn{2}{c}{ Infeksi } & \multirow{2}{*}{$\begin{array}{c}\text { Uji Chi } \\
\text { Square }\end{array}$} & Odds ratio \\
\cline { 1 - 2 } & Ya & Tidak & & \\
\hline Kortikosteroid & $31(50,82 \%)$ & $30(49,18 \%)$ & $\mathrm{P}=0,401$ & $1,5595 \%$ CI 0,56- \\
Non-kortikosteroid & $8(40 \%)$ & $12(60 \%)$ & & 4,32 \\
\hline
\end{tabular}


Analisis data uji statistik yang dilakukan menggunakan uji Chi Square didapatkan nilai $\mathrm{P}=0,401$ yang lebih tinggi dari 0,05 . Hal tersebut menyimpulkan tidak ada hubungan yang bermakna antara kejadian infeksi dengan penggunaan kortikosteroid pada pasien sindrom nefrotik. Nilai odds ratio kejadian infeksi didapatkan sebesar [OR] 1,55 95\% CI 0,56-4,32 dapat diartikan, kejadian infeksi pada pasien yang menggunakan kortikosteroid 1,55 kali lebih tinggi dibandingkan dengan pasien tanpa kortikosteroid.

Adanya variabel perancu penyebab infeksi yang tidak dikontrol pada penelitian ini memberikan keterbatasan pada penelitian. Adapun variabel perancu meliputi faktor lingkungan, riwayat penyakit pasien dan keluarga, adanya Kejadian Luar Biasa (KLB) dan riwayat imunisasi pasien.

\section{KESIMPULAN}

Hasil penelitian menunjukkan tidak ada hubungan yang signifikan antara kejadian infeksi dengan penggunaan kortikosteroid $(p=0,401)$. Walaupun demikian prevalensi kejadian infeksi pada pasien yang menggunakan kortikosteroid 1,55 kali lebih tinggi dibandingkan pasien yang tidak mendapatkan kortikosteroid.

\section{DAFTAR PUSTAKA}

Ajayan, P., Krishnamurthy, S., Biswal, N., Mandal, J, 2013, Clinical Spectrum and Predictive Risk Factors of Major Infections in Hospitalized Children with Nephrotic Syndrome. Indian Pediatric, 50 (8), pp 779-781. Doi 10.1007/s13312-013-0214-x.

Alatas, P. H., Tambunan, T., Trihono, P. P., Pardede, S. O, 2005, Konsensus Tatalaksana Sindrom nefrotik idiopatik pada anak. Unit Kerja Koordinasi Nefrologi Ikatan Dokter Anak Indonesia.

Aljebab F, Choonara I, Conroy S, 2017, Systematic Review of the Toxicity of LongCourse Oral Corticosteroids in Children. Dalam: Plos One Journal. University of Nottingham, United Kingdom. Hlm. 1-18.

Cohen EP., 2016, Nephrotic Syndrome,www.emedicine.medscape.com. was accessed on November 12, 2017.

Downie, M. L., Gallibois, C., Parekh, R. S., Noone, D. G, 2017, Nephrotic Syndrome in Infants and Children: Pathophysiology and Management. Pediatrics and International Child Health, 37 (4). doi. 10.1080/20469047.2017.1274003.

Hadisaputro S, Wibisono HB, 2011, Buku Ajar Geriati; Aspek Imunologik Pada Usia Lanjut, Edisi IV, FKUI, Jakarta. Hlm. 75-89.

Hull, R.P. and Goldsmith, D. J. A., 2008, Nephrotic Syndrome in Adults, 336 (May), pp. 1185-1189. Doi: 10.1136/bmj.39576.709711.80.

Jaipul, N., 2018, Overview of nephritic syndrome, http;www.Merckmanuals.com/ professional/genitourinary-disorders/glomerular-disorders/overview-ofnephrotic-syndrome, was accessed on January 29, 2019.

Katzung, B.G., 2018, Basic and Clinical Pharmacology, 14 ${ }^{\text {th }}$ Edition, McGraw-Hill Education, United State America. 
Kidney Disease Improving Global Outcomes (KDIGO), 2012, Clinical Practice Guideline for Glomerulonephritis. Kidney International Supplements. Hlm. 143153.

McCaffrey,J., Lennon, R. and Webb, N. J. A, 2016, The Non-immunosuppressive Management of Childhood Nephrotic Syndrome. Pediatric Nephrology. doi. 10.1007/s00467-015-3241-0.

Moorani, KM Khan, A Ramzan, 2011, Infection In Children With Nephrotic Syndrome. Dalam: J Coll Physicians Surg Pak Journal. National Institutes of Health, US. Hlm. 337-339.

Neugarten J, Acharya A, Silbiger SR, 2000, Effect of Gender on the Progression of Nondiabetic Renal Disease: A Meta-Analys. Dalam: J Am Soc Nephrol Journal. The Albert College Medicine, Bronx, New York. Hlm. 319-329.

Park, S. J. and Shin, J.I, 2011, Review article: Complications of Nephrotic Syndrome. Korean J Pediatr 2011;54(8):322-328.

Sweetman SC, 2009, Martindale: The Complete Drug Reference. Edisi 36. Pharmaceutical Press, London. Hlm. 1538-1539.

Sweetman SC, 2011, Martindale: The Complete Drug Reference. Edisi 37. Pharmaceutical Press, London. Hlm. 1677-1682.

Youssef, J., Novosad, S.A, Whinthrop, K. L, 2016, Infection Risk and Safety of Corticosteroid Use. Rheum Dis Clin North Am 2015. DOI: 10.1016/j.rdc.2015.08.004.

Zolotas, E., Krishnan, R. G, 2016, Nephrotic Syndrome, Pediatrics and Child Health (United Kingdom). Elsevier Ltd, 26 (8), pp. 349-352. doi: 10.1016/j.paed.2016.04.006. 